\title{
Management of Students' Vocational Training in Conditions of Social Partnership between the University and Industry
}

\author{
Svetlana G. Kashina ${ }^{a}$, Alexey D. Chudnovskiy ${ }^{\mathrm{b}}$, Natalia S. \\ Aleksandrovac, Igor V. Shamov $^{d}$ and Maria A. Borovaya ${ }^{e}$
}

aKazan State University of Architecture and Engineering, RUSSIA; ${ }^{b}$ Moscow State University of Management, RUSSIA; 'Vyatka Social-Economical Institute, RUSSIA; dVyatka State University, RUSSIA; eChuvash State Pedagogical University named after I. Y. Yakovlev, RUSSIA.

\begin{abstract}
In modern conditions of rapid development of science and technology, the rapid change of social processes in society there is an urgent need in mobile professionals who are able to effective work by the specialty on the world standards. This professionals' training can be provided only in a multi-channel interpenetration of educational processes, the content of educational curricula, training technology, organizational and management forms, financial and economic resources and production processes. In this regard, this article is aimed to identify features in the management of students' vocational training in conditions of social partnership of universities and enterprises. The leading approach in the study of this problem is an integrative approach that allows identifying of effective mechanisms of social partnership of universities and enterprises in the management of students' vocational training. The article reveals the essence of social partnership in vocational education, formulates its goals and objectives; justifies management principles of students' vocational training in conditions of social partnership; identifies the main directions of social partnership of vocational educational institutions and enterprises; reveals problems preventing the development of interaction in the system "high school - enterprise". Presented in the article materials may be useful for the administration of higher educational institutions and enterprises in dealing with problems related to the management of the integration of education and industry at the strategic, tactical and operational levels.
\end{abstract}

KEYWORDS

Management; vocational training; social partnership; University; industry
ARTICLE HISTORY

Received 15 September 2015

Revised 10 November 2015

Accepted 22 February 2016

CORRESPONDENCE Svetlana G. Kashina $\square$ kashina@kgasu.ru

(c) 2016 Kashina et al. Open Access terms of the Creative Commons Attribution 4.0 International License (http://creativecommons.org/licenses/by/4.0/) apply. The license permits unrestricted use, distribution, and reproduction in any medium, on the condition that users give exact credit to the original author(s) and the source, provide a link to the Creative Commons license, and indicate if they made any changes. 


\section{Introduction}

The relevance of the study is reasoned by the fact that Russian education is at a critical stage of its development. Education becomes a major factor for sustainable development of society, its competitiveness and national security. There is a need for specialists of a qualitatively new type who are competitive, proactive, competent, enterprising, highly skilled, communicative, having skills of business communication, knowledge of foreign languages, ready fully to work from the first working day, easily adapting to changes and quickly mastering new techniques and modern technology of modern high-tech manufacture, able to analyze complex situations and to make responsible decisions, owning innovative technology, manifesting an interest in permanent increase of the level of education and qualification (Ivanov et al., 2015; Sakhieva et al., 2015 a, b; Kalimullin \& Vasyagina, 2015; Lopatina et al., 2015; Baklashova et al., 2014, 2015). This need is caused by such socio-economic reasons, as the formation of a new geopolitical and economic environment of Russian Federation; dismantling of the planned socialist economy, the formation of the new, market-oriented economy; restructuring of the industrial sectors and social sphere, regionalization.

The socio-economic reality requires from the system of vocational training of such specialists, who immediately without adaptation period, internships can qualitatively perform specific duties professional activities and duties. The quality of education becomes the main mechanism to solve a whole set of social and economic problems that determine the country's development (Khairullina et al., 2016; Masalimova \& Sabirova, 2014 c; Vlasova et al., 2015, 2016; Lisitzina et al., 2015). A special place among the components of the quality of education is given to social partnership of secondary vocational education with a variety of social and economic institutions, which is understood as a system of joint activities, providing highly qualified workers' and mid-level professionals' training who are competitive and mobile in the labor market. Participants of social partnership are teachers, students and their parents, education authorities, state authorities and municipal self-government, employers (enterprises, industry associations and consortia), public organization. In practice, this is manifested in introducing of innovative training courses, implementing of new teaching technologies, developing of innovative design, increasing of the investment attractiveness of the vocational education system, improving of cooperation with local community, spreading of educational contracts, increasing of quality of education, expanding of the base of practical training, providing of the interaction of labor market and vocational education. Vocational training of students, carried out in conditions of social partnership of the University with social and economic institutions, requires the development of a new system of management.

\section{Literature Review}

\section{Managerial aspects of professional education}

In publications on management the principles and diagnosis of management, leadership's styles; roles and functions of the head, personnel's management and other problems are taken into consideration (Anikin, 2000; Vershigora, 2002; Vikhansky \& Naumov, 2002; Dracheva \& Yulikov, 2002; Fatkhutdinov, 2000). In the special literature on the problems of innovation management its functions 
and methods are identified; a management system of organization of innovation type and its structure is developed; the basis of innovative design are clarified, indicators of the efficiency of innovative activities are considered, the formation of a "portfolio of new and innovations" is studied (Anikin, 2000; Balabanov, 2001; Fatkhutdinov, 2002; Meskon, et al., 2002).

In works of scientists-psychologists the psychological aspects of the management process are considered (Andreyeva, 2001; Ilyin, 2009; Shakurov \& Alishev, 1997).

Various aspects of optimization of vital activities of educational institutions are revealed in the publications of G. A. Vinogradova (1995), V. I. Zvereva (1997), V. S. Lazarev (2002), N. B. Pugacheva (2000), T. I. Shamova et al (2002).

The management of educational institutions of basic vocational education was studied by P. F. Anisimov (2001), I. A. Bogachek (1990), I. P. Smirnov (2004), R. H. Shakurov (1995) and other specialists. In the works of these authors the system of comprehensive security of vocational education's management is studied, managerial project techniques are developed, factors that optimize the management of secondary vocational education.

\section{The role of social partnership}

In the research works, devoted to different aspects of social partnership in the educational environment, it is possible to find examples of successful interaction of enterprises with institutions of vocational education at all levels. For example, M. A. Zadorina \& I. V. Teslenko (2013) analyze the results of interaction between the entities of social partnership in professional education at all levels on the example of Sverdlovsk region. The paper notes a high level of graduate mobility, reveals the most popular specialties in Sverdlovsk region, gives the number of measures aimed to develop interaction of educational institutions with enterprises and organizations (cooperation with enterprises and organizations on the development of educational curricula in primary and secondary vocational education, conducting of students' practical training, additional incentive payments for some specialties). In her paper E. P. Sulayeva (2011) describes the activities aimed at the development of cooperation between Donetsk state industrial-humanitarian College with the administrations of organizations and enterprises of the city. Svirelkina I. I. and Gulin K. A. in their paper I. I. Svirelkina \& K. A. Gulin (2008) examine the condition of interaction between professional educational institutions and employers in the Vologda region. Main forms of cooperation are allocated: organization of training in enterprises and in the organizations, the enterprises' taking part in open doors' days, career fairs and conclusion of contracts on preparation of experts. It is noted that these forms are not sufficient for successful employment, as in the opinion of graduates so of employers. According to the study, the education system is more interested in attracting of business to the development of professional standards than the business itself.

In the paper of S. Yu. Sedunova \& V. V. Koroleva (2009) a model of organization of cooperation with employers in Pskov state pedagogical University is developed. Directions of development of interaction between universities and employers, as well as the expected results from the introduction of the model are presented. In the study of V. A Belikov et al. (2010) the problems of graduates' employment of institutions of primary and secondary 
vocational education and their solutions on the example of Magnitogorsk and Chelyabinsk regions are considered. In the paper of M. S. Chvanova et al. (2012) the practice of social partnership in Tambov state University named after G. R. Derzhavin is analyzed. One can mention the number of papers and dissertations devoted to the peculiarities of social partnership in colleges (Ignatiev, 2005; Amrenova et al, 2007) and universities (Bogacheva, 2007; Galanin, 2011). In the whole, most studies suggest a greater attention to the development of cooperation between business and educational community, about the need to develop new forms of cooperation and new ways to promote the interest of all social partners.

However, in scientific literature basic principles of social partnership of the University with the socio-economic institutions methodologically are not justified; the advanced experience of joint activities of professional educational institutions with different socio-economic structures in conditions of social partnership is not generalized.

\section{Results}

\section{The essence of social partnership in professional education}

Modern enterprises need specialists who are ready to work from the first day after graduation from the institute. For such specialists' training, it is necessary that in the formation of knowledge, abilities and skills the personnel's customers to participate as social partners of higher professional educational institutions. In conditions of social partnership "University - enterprise" there is a need in new management models for students' training. Under the management of students' vocational training in research a system of principles, functions, organizational-pedagogical conditions, criteria of management is understood based on social partnership "College - enterprise" aimed at improving of the quality of education and training of highly skilled workers and mid-level professionals, who are competitive and mobile in labor market.

Social partnership in vocational education is regarded in the paper as a form of cooperation between vocational education institutions with socioeconomic, political and public organizations, based on clear distribution of roles, responsibilities, equity participation, with the aim to train highly qualified workers and specialists, competitive and mobile in labor market. Social partnership in vocational education is a qualitatively new relationship between educational institutions, municipal and state government, employers, students and their parents.

\section{The goals and objectives of social partnership}

The purpose of the partners' interaction is interests' ensuring of all participants of educational process to prepare competent specialists that are in demand on the labor market.

The study shows that social partnership in vocational education allows:

- delegate to the companies the responsibility for determining of the needs for specialists and workers and for the planning of their training and retraining:

- change approaches to career guidance (using pre-profile training and specialized education);

- strengthen the links of educational institutions with the labor market 
through the involvement of employers and other social partners in developing of qualification requirements, procedures of knowledge's check, professional abilities and skills,

- strengthen the role of enterprises in competencies' teaching to meet specific production requirements

- involve social partners in the management, monitoring and evaluation of activities of educational institutions through procedures for their licensing and certification,

- facilitate the transition of educational institutions to the principle of selfgovernment, encouraging of their greater autonomy, the transition to economic methods of management, implementation of methods of outcomes' assessment and job placement of graduates.

\section{The main directions of social partnership}

Social partnership in the system "University - enterprise" contributes to the growth in the number of graduates prepared on the orders of the employer, employment who have full training and the improvement of their material situation, meeting of the needs of employers and students in training, growth of qualification level of graduates.

Social partnership in the system "University - enterprise" is also aimed at providing of in-service teacher training, modernization of material-technical base of educational institutions, stimulation and motivation of students and teachers, employment of graduates, career guidance, as with school-students so with the university-students and involves the creation of a marketing service of the educational institution.

\section{The principles of social partnership "University - enterprise"}

The study of the problem shows that social partnership "University - enterprise" is based on the following principles:

1) the principle of consistency, i.e. students' professional training is considered as a system with the following properties: the primacy of the whole (system), i.e. though the components form a whole (system) but it is more possible only because a whole makes possible the existence of the components; the non-additivity is the irreducibility of the system's properties to the sum of properties of constituent components and non-deducibility of properties of the whole system from properties of components; complexity of the system's structure, which is characterized by the number of hierarchy levels of the system's management; the diversity of components and connections, the complexity of behavior and non-additivity of properties, the amount of information necessary to manage; the vertical integrity of the system, i.e. the number of hierarchy levels and their degree of relationship, the degree of the managerial entity's influence on the object; the horizontal isolation of the system - the number of links between the sub-systems of the same level, their dependence and integration horizontally; a hierarchy nature of the system, whereby each component can be considered as a subsystem; the openness of the system, i.e. the intensity of informational exchange with the environment, the number of systems in the external environment interacting with the system, the degree of influence of other systems on the system, system's compatibility with other systems; focus of the system, which is understood as "tree of the purposes"; 
the priority of the quality of the various subsystems that ensures the survival of the system; emergence, i.e. the components' goals of the system may not coincide with the goals of the system; continuity and development of the system due to the contradictions in various spheres of activities, diversity of forms and methods of its functioning and development; the inertia of the system, i.e. the change's rate of output parameters of the system in response to changes in the input parameters; innovative nature of the system's activities, based on a variety of innovations, continuous development;

2) the principle of marketing orientation, i.e. the complex of works on creation of a portfolio of innovations, resource's saving and integrated development aimed at the needs of the labor market;

3) the principle of functionality, which consists in determining of the managerial entities' functions, the distribution of roles;

4) the principle of regulations' establishing to the management's subsystems (training, education, professional skills and other);

5) the principle of comprehensiveness, in which should be taken into account the technical, environmental, economic, organizational, social, psychological and, if necessary, and other (e.g., tender) aspects of management and their interrelation;

6) the principle of integration, i.e. the study and the linkages' strengthening among the management's entities, the development of co-management and selfgovernment;

7) the principle of legislative regulation of the functions, rights, responsibilities, quality standards, costs, duration, components of students' vocational training as a system, in the normative acts (orders, ordinance, instructions, standards, etc.);

8) the principle of pedagogical support, the purpose of which is to assist students in developing of their talents and creative abilities;

9) the principle of taking into account of a specific situation, according to which the suitability of different methods of management is determined by the specific situation.

The management of students' vocational training in conditions of social partnership "University - enterprise" has industrial-pedagogical nature and involves the ensuring of professional competence of the graduates on the basis of formation of the activities' competences (abilities and skills to perform professional activities) and communicative competences (abilities and skills of business communication), monitoring of the quality of vocational training; monitoring of professional adaptation of graduates of vocational educational institutions, organization of educational process in accordance with the requirements of employers to the graduates' qualification, certification of qualification characteristics of graduates with the participation of the social partners, the introduction in educational process of innovative pedagogical technologies, first of all, the module- competence ones, improvement of qualification of pedagogical staff, including through training of teachers and masters of industrial training at leading enterprises, possessing modern equipment and technology. 


\section{Discussions}

It should be noted that social partnership in the Russian Federation developed in a greater degree not as a result of social dialogue but as an initiative of the state in line with the overall strategy of society's reforming. In the 90 years it was the state who assumed a major role in the creation of organizational and legal mechanisms of social partnership's forming. Still existing in Russia model of interaction in the educational sphere is characterized by a high degree of state regulation. However, the state is interested in the increasing of the role of employers and educational institutions in the development of social partnership. Educational institutions, including universities, are focused on market's requirements, since the success of employment of graduates raises the status of the institutions themselves. Employers are the external consumers of educational services, because they hire graduates and expect a certain level of their qualification. In the state program of the Russian Federation "Development of education" for 2013-2020 y. (Ministry of education and science of the Russian Federation: State program of the Russian Federation "Development of education" for 2013-2020, 24.05.13) it is noted that the quality and flexibility of education can be achieved only with the active participation of all stakeholders, including students and employers. So the priority of education's development is the modernization of the educational sphere in the direction of more openness, more opportunities for initiatives and activities of the recipients of educational services by involving them in the management of the educational process and in educational activities. One of the objectives of the program is the increasing of employers' and public-private partnerships' role in the development of vocational education, in the result of which the employers will get professionals with "modern competencies, positive work attitudes and with practical experience" (Ministry of education and science of the Russian Federation: State program of the Russian Federation "Development of education" for 2013-2020, 24.05.13). In recent years, the increase of attention is noticeable to social partnership in the sphere of education, as at the state level, so from the side of employers and universities.

The essence of the proposed form of cooperation consists in the following tasks' solving: the study of the trends of development of the Russian economy and the impact of international labor market on it; analysis of the situation in sphere of staffing support of enterprises and organizations of the region and trends in requirements' changing to staff's skills; the study of the demand of economic entities for educational services; the study of labor market and market of educational services, development of mechanisms of their interaction.

To solve these problems, it is necessary to study not only the structure of the educational environment of the region, but also the trends' changing in the profile of the industrial environment, fundamentally affecting the labor market. Due to the lack of relevant information to the University to perform this analytical work it is required to get information directly from consumers of the staff, which once again emphasizes the need to integrate universities and business. 
It should be noted that there are major problems that prevent the development of interaction in the system "University - enterprise":

- the lack of tax breaks and other incentives at the Federal and regional levels in relation to companies and organizations that invest technical and financial resources in development of universities;

- weak legal and regulatory support for the interaction of universities with employers, vaguely defined status of the students' and postgraduates' target training in the interests of enterprises of different legal forms;

- contingency of researchers and engineering staff which is inadequate to the needs of industry and universities.

Despite the existing problems of interaction, social dialogue of higher vocational education and business benefits both sides and promotes the development of human capital.

\section{Conclusion}

Thus, the process of management of students' vocational training is based on social partnership of universities and enterprises, and is aimed at improving of the training's quality of competitive and mobile specialists in labor market.

Social partnership in vocational education is a form of cooperation of vocational educational institutions with the socio-economic, political and public organizations, based on clear distribution of roles, responsibility, equity participation, with the aim of competitive and mobile specialists in labor market. The purpose of the partners' interaction is the interests' ensuring of all participants of educational process (University, enterprises).

The presented in the paper principles of management of students' vocational training in conditions of social partnership "University - enterprise" include: consistency, marketing orientation, functionality, establishment of standards to management's subsystems (training, education, professional skills and other), complexity, integration, legislative regulation of the functions, rights, responsibilities, quality standards, costs, duration of students' vocational training, pedagogical support and taking into account of the specific situation.

Social partnership in the system "University - enterprise" contributes to the growth in the number of graduates prepared on the orders of the employer, employment who have completed training and the improvement of their material situation, meeting the needs of employers and students in training, growth of qualification level of graduates. Social partnership in the system "University - enterprise" is also aimed at providing of in-service teachers training, modernization of material-technical base of educational institutions, stimulation and motivation of students and teachers, employment of graduates, career guidance, as with school-students so with the university students and involves the creation of a marketing service of institution.

\section{Disclosure statement}

No potential conflict of interest was reported by the authors. 


\section{Notes on contributors}

Svetlana G. Kashina is $\mathrm{PhD}$, Associate Professor of Kazan State University of Architecture and Engineering, Kazan, Russia.

Alexey D. Chudnovskiy is PhD, Professor of Moscow State University of Management, Moscow, Russia.

Natalia S. Aleksandrova is PhD, Professor of Vyatka Social-Economical Institute, Kirov, Russia.

Igor V. Shamov is Postgraduate of Vyatka State University, Kirov, Russia.

Maria A. Borovaya is PhD, Associate Professor of Chuvash State Pedagogical University named after I. Y. Yakovlev, Kirov, Russia.

\section{References}

Amrenova, M. M., Naumova, E. E., Jurkiewicz, G. M. (2007) Social partnership is an important factor in the development of College. Vocational education, 5, 22-23.

Andreyeva, G. M. (2001) Social Psychology. Moscow: Aspekt Press. 377p.

Anikin, B. A. (2000) Highest management for managers. Moscow: INFRA-M. 136p.

Anisimov, P. F. (2001) Modern state and main directions of development of secondary vocational education. Secondary vocational education, 12, 5-9.

Baklashova, T. (2014) Managers' Professional Training in Russia: Syllabus and Technologies. Procedia - Social and Behavioral Sciences, 152, 1057-1061.

Baklashova, T. A., Galishnikova, E. M., Khafizova, L. V. (2015) The Effects of Education on Tolerance: Research of Students' Social and Ethnic Attitudes. Mediterranean Journal of Social Sciences, 6(1 S3), 335-340.

Balabanov, I. T. (2001) Innovation Management. St.Petersburg: Peter. 304p.

Belikov, V. A., Grishin, A. V., Makhnovsky, S. A. (2010) Social partnership in the system of primary and secondary vocational education. Bulletin of South Ural State University, 36 (212), 114-117.

Bogachek, I. A. (1990) Management of educational preparation of students in middle vocational school. Moscow: Higher school. 151p.

Bogacheva, O. V. (2007) Social partnership as a form of interaction between business and institutions of higher vocational education. Russian Entrepreneurship, 8(2), 142-146.

Chvanova, M. S., Khramov, M. V., Molchanov, A. A. (2012) Social partnership as a mechanism to improve social and innovation activities of higher education institution. Educational technology and society, 15(2), 581-601.

Dracheva, E. L., Yulikov, L. I. (2002) Management. Moscow: Mastery. 300p.

Fatkhutdinov, R. A. (2000) Innovation Management. Moscow: Business School "Intel-Synthesis". 270 p.

Fatkhutdinov, R.A. (2002) Production Management. Moscow: Publishing and Trading Corporation "Dashkov and K". 220p.

Galanin, Y. G. (2011) Social partnership of the University and the hotel enterprise in vocational training of tourism staff (Unpublished master's thesis). Moscow: Academia. 192p.

Ignatiev, N. S. (2005) Social partnership as a condition to improve the quality of specialists' training in the College (Unpublished master's thesis). Kazan: IPPPO RAO. 186p.

Ilyin, E. P. (2009) Psychology of will. St.Petersburg: Peter. 368p.

Ivanov, V. G., Shaidullina, A. R., Drovnikov, A. S., Yakovlev, S. A. \& Masalimova, A. R. (2015) Regional Experience of Students' Innovative and Entrepreneurial Competence Forming. Review of European Studies, 7(1), 35-40.

Kalimullin A. M. \& Vasyagina, N. N. (2015) Retrospective analysis of social and cultural meanings of motherhood in Russia. Review of European Studies, 7(5), 61-65.

Khairullina, E. R., Makhotkina, L. Yu., Kiryakova, A. V., Baranov, V. V., Maksimova, O. G., Khrisanova, E. G., Piralova, O. F., Masalimova, A. R. (2016) The real and the ideal engineertechnologist in the view of employers and educators. International Review of Management and Marketing, 6(1), 134-138. 
Lazarev, B. C. (2002) System development of the school. Moscow: Russian Pedagogical Society. $304 \mathrm{p}$.

Lisitzina, T. B., Kovaleva, N. I., Shaikhlislamov, A. K., Minsabirova, V. N., Shaidullina, A. R., Pavlova, N. A., Nevenchannaya, Y. V. (2015) Practical recommendations for the teachers on optimization process of the students majoring in Tourism. Asian Social Science, 11(1), 154-158.

Lopatina, O. V., Borisov, A. M., Leyfa, I. I., Galimzyanova, I. I., Yatsevich, L. P., Demyanenko, M. A. \& Masalimova, A. R. (2015) Role of foreign language teacher shaping students' research skills. Asian Social Science, 11 (4), 135-140.

Masalimova, A. R \& Sabirova, L. L. (2014) Multi-dimensional classification of types and forms of corporate education. American Journal of Applied Sciences, 11, 1054-1058.

Meskon, M., Albert, M., Hedouri, F. (2002), Fundamentals of Management: Moscow: Delo, 704p.

Ministry of education and science of the Russian Federation: State program of the Russian Federation "Development of education" for 2013-2020. Retrieved May 24, 2013 from http://минобрнауки.pф/документы/3409

Pugacheva, N. B. (2000) Theory and practice of political socialization. Izhevsk: SACA. 241p.

Sakhieva, R. G., Gilmanshina, S. I., Gilmanshin, I. R., Kosmodemyanskaya, S. S., Akchurina, I. R. \& Sagitova, R. N. (2015a) A Portfolio as an Alternative Means of Presenting the University student's Achievements. Asian Social Science. 11 (3), 162-167.

Sakhieva, R. G., Majkova, L. V., Emelyanova, M. V., Gavrilova, N. G., Sharonova, E. G., Gatina, A. R., Pavlova, N. A., Baklashova, T. A. (2015b) The Supplementary Education Teacher's Portfolio: Essence, Functions, Structure and Design Principles. Mediterranean Journal of Social Sciences, $6(2$ S3), 84-90.

Sakhieva, R. G., Semenova, L. V., Muskhanova, I. V., Yakhyaeva, A. Kh., Iskhakova, R. R., Makarova, E. V. \& Shafigullina, L. Sh. (2015c) Academic mobility of high school students: concept, principles, structural components and stages of implementation. Journal of Sustainable Development, 8 (3), 256-262.

Sedunova, S. Y. \& Koroleva, V. V. (2009) Models The models of cooperation between high school and employers. Bulletin of the Pskov State University, 9, 154-158.

Shakurov, B. C. \& Alishev, B. S. (1997) Psychology of management activities in vocational school. Kazan: ISSO RAO. 124p.

Shakurov, B. C. (1995) A new psychological concept of activities: a system dynamics approach. Professional education, 1, 31-38.

Shamova, T. I., Davydenko, T. M., Shibanov, G. N. (2002) Management of educational systems. Moscow: "Academy". 320p.

Smirnov, I. P. \& Tkachenko, E. V. (2004) Social partnership: What will happen with employers? Moscow: "Aspect". 132p.

Sulayeva, E. P. (2011) Social partnership between educational institution and industry as a condition for the formation of entrepreneurial competence of College students. Recent studies of social problems Krasnoyarsk, 8 (4), 75-80.

Svirelkina, I. I. \& Gulin, K. A. (2008) The Development of social partnership in professional education of the region. Economic and social changes in the region, 44, 73-81.

Vershigora, E. E. (2002) Management. Moscow: INFRA-M. 282p.

Vikhansky, O. S. \& Naumov, A. I. (2002) Management: man, strategy, organization, process. Moscow: Gardariki. 528p.

Vinogradova, G. A. (1995) Moral and analytical climate and skill of the teacher. Izhevsk: Publishing House of the Udmurt State University. 123p.

Vlasova, V. K., Kirilova, G. I., Curteva O. V. (2016) Matrix classification of information environment algorithms application in the educational process. Mathematics Education, 11(1), 165-171.

Vlasova, V. K., Kirilova, G. I., Sabirova, E. G. (2015) Functioning of information educational environment: Meta dynamic approach. Review of European Studies, 7 (5), 25-30.

Zadorina, M. A. \& Teslenko, I. V. (2013) Study of social partnership in professional education at regional level. Monitoring of public opinion 5 (117), 67-70.

Zvereva, V. I. (1997) Organizational-pedagogical activity of the school leader. Moscow: New School. 319 . 